\title{
PENGARUH KUALITAS PRODUK, HARGA DAN MEREK TERHADAP KEPUTUSAN PEMBELIAN HAND SANITIZER NATURE LEAF PADA REMAJA DI SURAKARTA
}

\author{
${ }^{1}$ Nia Rahma Astuti, ${ }^{2}$ Andri Nurtantiono \\ Sekolah Tinggi Ilmu Ekonomi Surakarta \\ E-mail: niarahmaa1703@gmail.com,annurtantiono@gmail.com
}

\begin{abstract}
INTISARI
Artikel ini dibuat untuk membuktikan bahwa keputusan pembelian Hand Sanitizer Nature Leaf di Remaja Surakarta dipengaruhi Oleh Kualitas Produk, Harga dan Merek. Analisis Regresi Linier Berganda dipilih sebagai metode penelitian ini tentunya menggunakan SPSS versi 2016. Hasil yang didapat ialah keputusan pembelian dipengaruhi kualitas produk, untuk variable harga menujukkan adanya dampak signifikan \& Untuk variable Merek memperlihatkan adanya dampak signifikan dimana keputusan pembelian dipengaruhi oleh Merek
\end{abstract}

Kata kunci: Kualitas Produk, Harga, Merek, Keputusan Pembelian.

\section{ABSTRACT}

This article was created to prove that the decision to purchase Hand Sanitizer Nature Leaf in Remaja Surakarta is influenced by product quality, price and brand. Multiple Linear Regression Analysis was chosen as the research method of course using the 2016 version of SPSS. The result obtained is the purchase decision is influenced by the quality of the product, for variable prices showed a significant impact \& For variable Brands showed a significant where the purchase decision was influenced by the Brand

Key Word: Product Quality, Price, Brand, Purchase Decision.

\section{PENDAHULUAN}

Akibat adanya pandemi Covid-19 yang sudah hampir berjalan 6 bulan, menyebabkan banyaknya kebutuhan produk kebersihan bagi masyarakat semakin meningkat. Virus Corona ini merupakan virus dari Negara China, tepatnya di Wuhan yang baru ditemukan pada akhir 2019 kemarin. Virus ini mengakibatkan gangguan pada system pernafasan, bercak pada paru - paru yang berujung kematian. Virus ini menular dengan sangat cepat dan seluruh Negara di dunia, termasuk Indonesia. Pemerintah bergerak cepat untuk menangani virus ini, Cara yang diterapkan pemerintah adalah menerapkan protocol kesehatan, yaitu dengan mencuci tangan menggunakan sabun, memakai masker yang sudah ditetapkan standarnya oleh Pemerintah, dan menjauhi kerumunan. Oleh karena itu kebutuhan produk kebersihan semakin meningkat, Salah satunya adalah kebutuhan hand sanitizer . Karena dalam protocol kesehatan juga diterapkan untuk menghindari penyebaran kuman atau virus terutama pada tangan kita. Karena kuman atau virus ini akan menyebar sangat cepat melalui kontak fisik seperti tangan.

Oleh karena itu untuk memenuhi kebutuhan masyarakat maka Cv. Surya Putra Kimindo membuat produk Hand Sanitizer yang diberi nama "Nature Leaf". Nature leaf merupakan produk hand sanitizer yang tidak lengket dan memiliki bau yang khas seperti berbau rempah. Cv. Surya Putra Kimindo bertempat di Grogol, Sukoharjo jadi sangat mudah dijangkau oleh konsumen dan konsumen bisa membeli produknya tanpa harus membeli produk lain yang susah di dapat. Nature leaf memiliki kualitas produk yang tidak kalah dengan pesaingnya, kualitas produknya tentu sudah di uji dengan laboratorium. Untuk Harga produk ini tentu sangat jauh lebih terjangkau daripada merk serupa, seperti Dettol, Antis, dan lain lain. 
Sedangkan Merk "Nature Leaf"sangat mudah di ingat konsumen karena Hand Sanitizer ini memiliki bau yang khas seperti rempah hal ini yang membuat konsumen beranggapan "Nature Leaf" merupakan produk natural atau alami. Untuk daerah Surakarta sendiri masih ada peningkatan pasien Covid - 19 sampai awal bulan November ini karena mereka banyak yang tidak menerapkan protocol kesehatan yang salah satunya adalah memakai hand sanitizer. Oleh karena itu, artikel ini adalah "Pengaruh Kualitas Produk, Harga dan Merek terhadap keputusan pembelian Hand Sanitizer Nature leaf pada Remaja Di Surakarta"

Variabel yang dipilih penulis yang pertama adalah kualitas produk, Kualitas produk merupakan ciri yang dimiliki perusahaan untuk meyakinkan bahwa mereka mampu memenuhi kebutuhan pelanggan dan telah dipatenkan (Kotler dan Amstrong, 2008). Dalam penelitian sebelumnya yang dilakukan pada konsumen PT. Astra International Tbk Daihatsu cabang malalayang tentang Faktor yang mempengaruhi Keputusan pembelian Grand Max pada, dalam penelitian ini menunjukkan bahwa adanya pengaruh antara dua variable tersebut dalam terhadap keputusan pembelian yang dilakukan konsumen terhadap Mobil Grand Max Pick Up pada Daihatsu cabang malalayang (Igir, Tampi, Taroreh, 2018). Variabel selanjutnya adalah Harga, Harga adalah unsur yang menghasilkan pendapatan bagi perusahaan sebagai ganti atas sejumlah produksi (Jasa \& Bahan baku ) yang menghasilkan produk yang mereka buat sesuai dengan kualitas atas produk (Kotler \& Keller, 2008). Harga merupakan hal salah satu yang digunakan pembeli sebagai acuan untuk melakukan pembelian akan sebuah produk. Konsumen tentu akan mempertimbangkan pembelian mereka, apakah harga yang dibeli mereka sebanding dengan kualitas yang mereka dapat. Dalam penelitian yang menguji tentang factor yang berpengaruh terhadap keputusan pembelian Yamaha R15 di Yogyakarta menunjukan bahwa tiap tiap variable yaitu, dimana Keputusan pembelian ini memiliki keterikatan atau kaitan secara langsung terhadapKualitas produk, persepsi harga, dan Citra merek dari motor tersebut (Rizal Dwi Ananta, 2018). Dan dalam penelitian terdahulu yang dilakukan tentang Faktor yang mempengaruhi pkeputusan pembelian wardah pada Mahasiswi Universitas Muhammadiyah Surakarta menunjukan bahwa tiap tiap Variabel yaitu, Harga karena dalam produk wardah ini memang terkenal dengan brand yang halal serta memiliki harga terjangkau, dan dapat dibuktikan dalam penelitian ini. serta kualitas produk yang tidak kalah berperan penting dalam merambahnya wardah di kalangan remaja utamanya, Dan tentunya skualitas produk memiliki pengaruh terhadap keputusan pembelian (Ela Karisma Putri, 2016)

Variabel yang ketiga adalah Merek. Menurut Sutodjo (2009) merek merupakan symbol atau logo dari sebuah perusahaan agar mudah diingat konsumen. Dalam Penelitian dengan Keputusan pembelian Iphone di STIE Eben Haezar Manado menunjukkan bahwa kesimpulan analisis statistik ternyata merek merupakan hal yang utama saat konsumen akan membeli sesuatu dan disini dijelaskan bahwa Merek sangat berpengaruh terhadap keputusan pembelian Iphone. Yang kedua ialah desain produk, tentu sebagai pelopor Ios yang sangat terkenal di penjuru dunia Iphone memiliki desain yang sangat menarik dan tidak monoton bahkan desain dari Iphone secara berkala akan dirombak atau ditambahkan dengan fitur yang lebih mumpuni, dengan kata lain kedua variable memiliki hasil positif. Dan yang ketiga adalah kualitas produk, Iphone tidak akan mengecewakan konsumen nya dengan cara perusahaan tersebut memberikan kualitas Ios yang belum dikeluarkan oleh pesaingnya inilah yang menjadikan Iphone memiliki daya tarik tersendiri bagi konsumen Iphone khususnya sehingga mempengaruhi keputusan pembelian konsumen Iphone (Gloria Tengor, Lotje Kawet, 2016) Dan dalam penelitian Surya Sanjaya (2015) yang menguji Promosi dan Merek untuk produk PT. Sinar Sosro Medan, seperti yang kita tahu bahwa Merek minuman sosro ini sangat terkenal di Indonesia karena kualitas dan pelayanan perusahaan ini tentunya dengan berbagai upaya seperti promosi yang dilakukan Sosro akan berpengaruh besar terhadap penjualanya, 
yang dalam penelitian ini keduanya memiliki hasil yang positif. Variabel terikat dalam penelitian ini ialah Keputusan Pembelian. Schiffman dan Kanuk (2009 : 112) mengatakan bahwa Keputusan pembelian ialah hasil penentuan diantara beberapa produk yang mereka inginkan kemudian menentukan apa yang harus dibeli atas suatu produk atau jasa.

Tentunya penelitian ini dilakukan untuk membuktikan bahwa Keputusan pembelian Hand Sanitizer Nature Leaf pada remaja di Surakarta dipengaruhi oleh Kualitas Produk, Harga dan Merek. Riset ini dilakukan karena Harga produk Nature Leaf sangat terjangkau bagi semua kalangan, terutama adalah kalangan remaja. Karena banyak remaja yang memiliki segudang aktivitas di ruang terbuka dan dihimbau untuk tetap menjaga kebersihan terutama tangan yang rentan terhadap kuman agar terhindar dari virus penyakit yang sedang merebak di penjuru dunia. Table dibawah ini menunjukkan perbedaan antara Nature Leaf dan Pesaingnya.

Tabel 1. Daftar Harga Nature Leaf dan Pesaing

\begin{tabular}{|c|c|c|}
\hline MEREK & KEMASAN & HARGA \\
\hline Nature Leaf & Botol $100 \mathrm{ml}$ & $\mathrm{Rp} \quad 20.500$ \\
\hline Nature Leaf & Botol $500 \mathrm{ml}$ & $\mathrm{Rp} \quad 110.000$ \\
\hline Nature Leaf & Jerigen 1 liter & $\mathrm{Rp} \quad 156.000$ \\
\hline Nature Leaf & Jerigen 5 liter & Rp $\quad 345.000$ \\
\hline Gel One Med & $500 \mathrm{ml}$ & $\mathrm{Rp} \quad 123.219$ \\
\hline Dettol & $50 \mathrm{ml}$ & $\mathrm{Rp} \quad 37.242$ \\
\hline Antis & $55 \mathrm{ml}$ & $\begin{array}{ll}\mathrm{Rp} & 25.541 \\
\end{array}$ \\
\hline
\end{tabular}

Sebenarnya kebutuhan akan produk kebersihan hand sanitizer sudah dipenuhi oleh para produsen Hand Sanitizer akan tetapi banyak produk yang harganya tidak terjangkau khususnya untuk kaum remaja. Salah satu brand hand sanitizer yang terjangkau yaitu Nature Leaf. Nature Leaf memiliki harga yang jauh lebih terjangkau daripada produk pesaing sejenisnya, akan tetapi memiliki kualitas dan mutu yang tidak kalah bagus.

\section{TINJAUAN PUSTAKA DAN PENGEMBANGAN HIPOTESIS}

Kotler dan Keller (2016: 27) mengemukakan manajemen pemasaran ialah proses menciptakan, mengomunikasikan, menyampaikan serta bertukar untuk sebuah penawaran bagi konsumen.

Pemasaran dalam sebuah organisasi sangatlah penting karena menjadi tolak ukur untuk mengetahui apa yang diinginkan oleh konsumen pasar serta bagaimana cara memuaskan konsumen dengan tetap memperhatikan tujuan organisasi itu sendiri.

\section{Keputusan Pembelian}

Schiffman dan Kanuk (2009 : 112) mengatakan bahwa Keputusan pembelian ialah hasil penentuan diantara beberapa produk yang mereka inginkan kemudian menentukan apa yang harus dibeli atas suatu produk atau jasa. Di sebuah keputusan pembelian tentu seorang konsumen akan benar benar mempertimbangkan langkah yang mereka ambil untuk melakukan pembelian sebuah produk atau jasa. Sebelum memutuskan produk yang dipilih sebaiknya konsumen mempertimbangkan merek, pemasok dan tipe produk apa yang sesuai dengan kebutuhanya dengan cara melakukan pencarian atas produk yang bersangkutan kemudian akan dibandingkan dengan produk alternatif lainya. Konsumen memiliki beberapa indicator untuk melakukan keputusan pembelian, Ada lima indicator Keputusan Pembelian menurut Kotler \& Keller (2012:178)

1. Alternatif Product

2. Alternatif Merk

3. Alternatif Distributor 
4. Waktu pembelian

5. Metode Pembayaran

Dengan adanya indicator tersebut tentunya sebagai produsen akan lebih mudah memahami apa yang diinginkan konsumen, dan produsen seharusnya memberikan jalan keluar atau solusi untuk menarik konsumen dengan caranya masing masing.

\section{Kualitas Produk}

Kotler dan Amstrong (2008) mengatakan ciri yang dimiliki perusahaan untuk memenuhi kebutuhan pelanggan dan telah dipatenkan disebut Kualitas Produk. Kualitas produk juga dapat menjadi acuan bagi produsen untuk menarik konsumen, dengan adanya kualitas produk yang tinggi akan menambah nilai jual yang tidak dimiliki produk sejenisnya atau produk pesaingnya. Dalam penelitian sebelumya yang dilakukan oleh Friani Gloria Igir, Jhony R. E Tampi dan Henny Taroreh (2018) yang menguji adanya pengaruh Kualitas produk dan Harga pada Grand Max bertempat di PT. Astra International Tbk. Daihatsu cabang Malalayang dapat dilihat bahwa Kualitas Produk mobil ini memanglah mumpuni dan sangat menarik bagi konsumenya. oleh karena itu Kualitas produk ini berpengaruh terhadap pembelian Grand Max Pick Up. Dalam Penelitian yang lain juga yaitu dalam riset Rizal Dwi Ananta (2018) yang menguji tentang factor yang mempengaruhi keputusan pembelian Motor Yamaha R15 di daerah Yogyakarta dapat disimpulkan jika kualitas produk dari motor ini sendiri memanglah menjadi salah satu keistimewaan tersendiri bagi konsumen yang akan membeli motor Yamaha R15 di Yogyakarta.

Produk yang memiliki keunggulan yang lebih dari pesaing tentu akan dijadikan sebagai pilihan pertama oleh konsumen, oleh karena itu kualitas produk bisa dikatakan sebagai hal yang utama dalam sebuah produk. Adapun indicator kualitas produk menurut Tjiptono $(2010: 25)$ antara lain :

1. Performa dari produk yang dirasakan konsumen

2. Keunggulan tambahan dari produk

3. Keterampilan produk

4. Kecocokan dengan spesifikasi antara produk dengan apa yang diharapkan konsumen.

5. Tingkat kemampuan produk dalam bekerja

6. Keindahan pengemasan dalam produk.

\section{Harga}

Harga adalah unsur yang menghasilkan pendapatan bagi perusahaan sebagai ganti atas produk yang mereka buat (Kotler dan Keller, 2008). Harga dapat dikatakan menjadi peran utama bagi konsumen untuk melakukan pembelian dalam segala hal. Dengan adanya harga, seorang produsen dapat menetukan pangsa pasar mereka dan dapat memperkirakan berapa keuntungan yang hendak mereka dapat. Dalam penelitian yang dilakukan Ela Karisma Putri (2016) tentang factor harga dalam pembelian kosmetik Wardah di Universitas Muhammadiyah Surakarta dapat disimpulkan bahwa secara langsung berpengaruh atas pembelian Kosmetik wardah di Universitas MuhammadiyahSurakarta. Harga juga memiliki beberapa indicator, salah satunya adalah menurut Kotler \& Amstrong (2008) antara lain :

1. Harga yang terjangkau bagi konsumen

2. Kesesuaian nilai yang dikeluarkan konsumen sepadan sengan yang didapat konsumen

3. Keunggulan yang dapat dilihat dari produk lain

4. Kesesuaian nilai yang dikeluarkan konsumen dengan kegunaan yang diperoleh konsumen 


\section{Merek}

Menurut Sutodjo (2009) merek ialah sebuah symbol dan dapat dikatakan juga sebagai logo dari sebuah perusahaan agar mudah diingat konsumen. Merek merupakan hal yang paling mudah diingat oleh konsumen karena merek biasanya dibentuk dengan logo, symbol bahkan gambar yang mudah diingat oleh konsumen. Oleh karena itu merek disebut juga sebagai atribut pelengkap dari sebuah produk. Biasanya logo atau symbol bahkan gambar dari sebuah produk memiliki makna tersendiri yang di desain khusus oleh perusahaan.

Dalam Penelitian factor yang mempengaruhi Keputusan pembelian Iphone pada STIE Eben Haezar Manado menunjukkan bahwa hasil analisis statistik ternyata merek merupakan hal yang utama saat konsumen akan membeli sesuatu dan disini dijelaskan bahwa Merek sangat berpengaruh terhadap keputusan pembelian Iphone. Yang kedua ialah desain produk, tentu sebagai pelopor Ios yang sangat terkenal di penjuru dunia Iphone memiliki desain yang sangat menarik dan tidak monoton bahkan desain dari Iphone secara berkala akan dirombak atau ditambahkan dengan fitur yang lebih mumpuni. Oleh karena itu hal ini menunjukkan jika desain produkmemiliki pengaruh. Dan yang ketiga adalah kualitas produk, Iphone tidak akan mengecewakan konsumen nya dengan cara perusahaan tersebut memberikan kualitas Ios yang belum dikeluarkan oleh pesaingnya inilah yang menjadikan Iphone memiliki daya tarik tersendiri bagi konsumen Iphone khususnya. Dalam artikel ini keputusan pembelian dipengaruhi oleh Kualitas Produk (Tengor, Kawet, Loindong, 2016). Penelitian Surya Sanjaya (2015) yang meneliti factor yang mempengaruhi keputusan pembelian pada PT. Sinar Sosro Medan ,seperti yang kita tahu bahwa Merek minuman sosro ini sangat terkenal di Indonesia karena kualitas dan pelayanan perusahaan ini tentunya dengan berbagai upaya seperti promosi yang dilakukan Sosro akan berpengaruh besar terhadap penjualanya. Hal ini dibuktikan jika adanya keterikatan antar variable terhadap keputusan pembelian. Adapun indikator dari Merek menurut Aaker (2008: 23) terdiri daribeberapa faktor yaitu:

1. Konsumen memiliki pengetahuan tentang Merek

2. Konsumen memiliki kesan akan kualitas

3. Kesan yang melekat pada sebuah produk

4. Kekuatan preferensi terhadap merek satu dengan merek lainya.

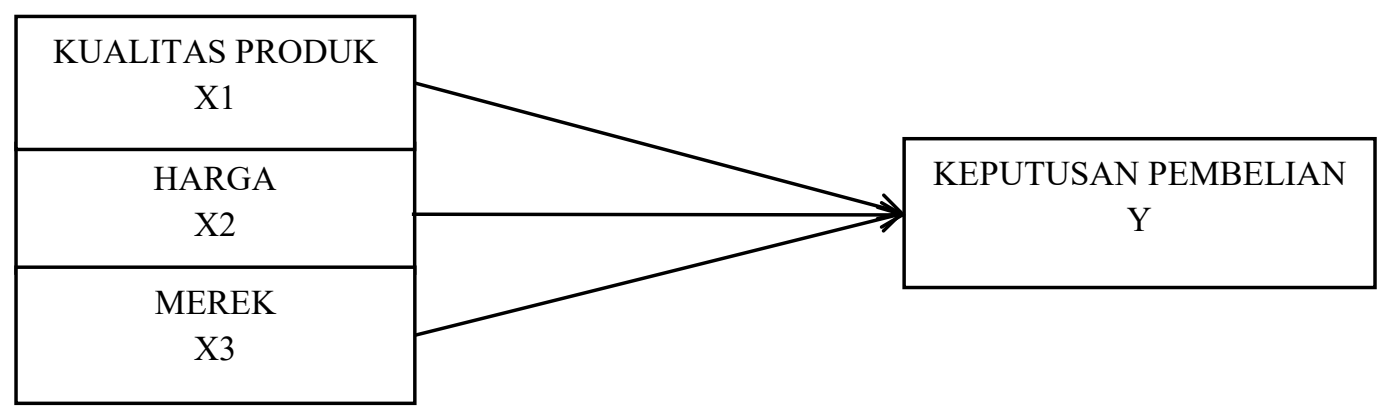

Gambar 1. Kerangka Pemikiran

Tentunya artikel ini memiliki perbeedaan dengan pendahulunya yaitu, Objek penelitian itu sendiri, Untuk penelitian ini menggunakan objek "Nature Leaf" dan dari segi waktu penelitianpun juga berbeda serta objek lokasi penelitian itu sendiri.

Dalam artikel yang saya buat ini memiliki perbedaan dengan artikel sejenisnya yang sudah di publikasikan, seperti hasil penelitian Hariman Syaleh (2017) tentang pengaruh Kualitas Produk motor yamaha kemudian Harga dari motor itu sendiri yang diketahui bahwa harga motor Yamaha lebih mahal daripada pesaingnya karena mereka memiliki keunggulan yang lebih dari yang lain, Promosi serta pendistribusian berdasarkan tempatnya yaitu pada $\mathrm{CV}$. Tjahaja Baru Bukit tinggi menunjukan jika hasil riset tersebut kualitas dari 
motor Yamaha memiliki pengaruh terhadap keputusan pembelian Yamaha begitu pula tempat distribusinya,sedangkan harga tidak memiliki keterikatan terhadap keputusan pembelian.

\section{Pengembangan Hipotesis}

Dalam riset yang dilakukan penulis ini terdapat tiga acuan untuk awal penelitian yang telah di dasarkan pada penelitian terdahulu dan teori :

H1 : Keputusan Pembelian Nature Leaf pada remaja Surakarta dipengaruhi Oleh Kualitas Produk.

H2 : Keputusan Pembelian Nature Leaf pada remaja Surakarta dipengaruhi Oleh Harga.

H3 : Keputusan Pembelian Nature Leaf pada remaja Surakarta dipengaruhi Oleh Merek.

\section{METODE PENELITIAN}

Daerah Surakarta, terutama di Pusat pendidikan seperti Sekolah, Universitas, Apotek ataupun Supermarket menjadi Objek dalam penelitian ini. Data Primer ialah data asli kemudian dikutip dari orang yang secara umum kita sebut sebagai narasumber (Sarwono, 2012). Responden dari hasil kuesioner konsumen Remaja Nature Leaf di Surakarta menjadi sumber kutipan asli dari narasumber untuk riset yang dilakukan penulis.Sumber data sekunder adalah hasil pekerjaan atau kumpulan hal yang penting dalam perusahaan yang biasanya dipublikasikan lewat media social, Web internet dan lain lain (Uma Sekaran, 2011). Data ini diperoleh dari Laporan Penjualan Cv. Surya Putra Kimindo itu sendiri selama beberapa bulan terakhir.

Populasi adalah suatu tempat, di dalamnya mencakupbeberapa hal menyangkut dan sesuai dengan kriteria kitadan ditetapkan peneliti untuk melakukan penelitian mereka (Sugiyono, 2011). Konsumen Nature Leaf terutama konsumen remaja menjadi Populasi dalam artikel ini, Dalam Penelitian ini juga populasinya tidak terbatas.Sampel adalah separuh Populasi yang pantas dijadikaan ciri yang dimiliki oleh peneliti kemudian kita tarik kesimpulan dari sampel tersebut sesuai penelitian yang telah kita lakukan (Sugiyono, 2011). Dalam artikel ini menggunakan populasi tidak terbatas dengan menerapkan rumus sampel dari Rao Purba (Sujarweni, 2015) dan ditemukan hasil jika responden yang dijadikan sampel adalah 100 orang.

Rumus Rao Purba;

Keterangan:

$$
n=\frac{Z^{2}}{4(m o e)^{2}}
$$

$\mathrm{n}=$ Banyaknya orang yang ditetapkan penulis

$\mathrm{Z}=$ tingkat keyakinan dalam penentuan sampel $(95 \%=1,96)$

Moe $=$ margin of error kesalahan maksimum yang bisa ditolerir sebesar $10 \%$

Berdasarkanperhitungan diatas maka hasilnya sebagai berikut:

$$
\begin{aligned}
n & =\frac{(1,96)^{2}}{4(0,1)^{2}} \\
& =\frac{3,8416}{0,04} \\
& =96,04
\end{aligned}
$$

Dengan menerapkan teknik sampel Non Probability Sampling dengan teknik sampling yaitu Purposive Sampling karena memperhatikan tingkatan populasi yang ada yaitu remaja di Surakarta. Alasan karena saya memilih objek di Surakarta karena di Surakarta masih ada 
peningkatan penderita Covid -19 dan hal ini dikarenakan tidak menerapkan protokol kesehatan. Saya memilih Remaja Surakarta dengan kriteria yaitu:

1....Remaja yang memiliki aktivitas diluar rumah seperti sekolah, bekerja dan lain lain.

2....Remaja yang sudah pernah membeli hand sanitizer Nature Leaf.

Analisis regresi linear berganda diterapkan di riset kali ini sekaligus menggunakan Spss versi 16. Menurut Sugiyono (2017 : 275) analisis ini digunakan apabila peneliti meramalkan apa saja yang menjadi pengaruh naik turunya keadaan variable dependen terhadap variable independen.Menurut Sugiyono (2012 : 61) Variabel penelitian ialah kegiatan memilih hal yang dapat menjadi factor atau penyebab yang sudah diambil oleh peneliti untuk kemudian ditarik kesimpulan nya. Artikel ini ada 4 variabel yaitu Keputusan pembelian, Kualitas Produk, Harga dan Merek karena peneliti memiliki asumsi jika dalam keputusan pembelian konsumen akan membandingkan variable tersebut.

Menurut Swastha (2007 : 68) Keputusan pembelian yaitu hal yang menjadi pertimbangan konsumen untukmenukar sejumlah uangnya untuk produk bahkan layanan yang dapat kita nikmati yang berpengaruh pada tingkah laku setelah pembelian. Menurut Kotler dan Amstrong (2008 : 272) Kualitas produk merupakan factor yang berhubungan langsung di produk atau jasa yang sudah dibeli konsumen. Dan tentunya kualitas ini dijadikan konsumen untuk melakukan Repeat Buying.

Menurut Kotler dan Amstrong (2008 : 345) Harga adalah sejumlah nilai pengganti yang diberi oleh konsumen akan suatu produk atau jasa. Sedangkan Merek menurut Aaker (2008) adalah nilai yang menjadi tolak ukur dimata konsumen dalam bentuk Symbol atau nama.

\section{HASIL DAN PEMBAHASAN}

Tabel 2 Uji Validitas

\begin{tabular}{lllll}
\hline Variabel & Item Pertanyaan & $\mathbf{r}_{\text {hitung }}$ & $\mathbf{r}_{\text {tabel }}$ & Keterangan \\
\hline \multirow{4}{*}{ Kualitas } & X1.1 & 0.635 & 0.1654 & VALID \\
Produk & X1.2 & 0.608 & 0.1654 & VALID \\
& X1.4 & 0.673 & 0.1654 & VALID \\
& X1.5 & 0.603 & 0.1654 & VALID \\
& X1.6 & 0.612 & 0.1654 & VALID \\
& X2.1 & 0.367 & 0.1654 & VALID \\
Harga & X2.2 & 0.659 & 0.1654 & VALID \\
& X2.3 & 0.752 & 0.1654 & VALID \\
& X2.4 & 0.743 & 0.1654 & VALID \\
& X3.1 & 0.544 & 0.1654 & VALID \\
Merek & X3.2 & 0.656 & 0.1654 & VALID \\
& X3.3 & 0.671 & 0.1654 & VALID \\
& X3.4 & 0.685 & 0.1654 & VALID \\
Keputusan & Y1.1 & 0.689 & 0.1654 & VALID \\
Pembelian & Y1.3 & 0.629 & 0.1654 & VALID \\
& Y1.4 & 0.688 & 0.1654 & VALID \\
& Y1.5 & 0.732 & 0.1654 & VALID \\
\hline Sumber & Data & 0.705 & 0.1654 & VALID \\
\hline
\end{tabular}

Sumber : Data Primer, SPSS (2020) 
Dari Tabel 2 diatas dapat disimpulkan jika hasil data yang diolah adalah valid karena indikator Kualitas Produk, Harga serta Merek Dan Keputusan Pembelian hasil nilai $r$ hitung $>$ r table.

\section{Tabel 3 Uji Reliabilitas}

\begin{tabular}{lllll}
\hline No & \multicolumn{1}{c}{ Variabel } & Croncbach's Alpha & Batas Normal & Keterangan \\
\hline 1 & Kualitas Produk & 0.607 & $>0,60$ & Reliabel \\
2 & Harga & 0.601 & $>0,60$ & Reliabel \\
3 & Merek & 0.603 & $>0,60$ & Reliabel \\
4 & Keputusan Pembelian & 0.698 & $>0,60$ & Reliabel \\
\hline \multicolumn{2}{l}{ Sumber: Data Primer, SPSS (2020) }
\end{tabular}

Dari Tabel 3 diatas diketahui bahwa hasil data yang diolah memiliki hasil bahwa nilai variable Kualitas Produk, Harga dan Merek menghasilkan nilai Croncbach's Alpha >0.6 dan dapat dikatakan jika semua instrument dalam penelitian ini tergolong reliable.

\section{Tabel 4 Uji Normalitas}

\begin{tabular}{lll}
\hline \multicolumn{2}{c}{ One-Sample Kolmogorov-Smirnov Test } \\
\hline & & $\begin{array}{l}\text { Unstandardized } \\
\text { Residual }\end{array}$ \\
\hline $\mathrm{N}$ & Mean & 100 \\
Normal Parameters ${ }^{\mathrm{a}}$ & Std. Deviation & .0000000 \\
& Absolute & 1.52872310 \\
Most Extreme Differences & Positive & .041 \\
& Negative & .041 \\
Kolmogorov-Smirnov Z & & -.039 \\
Asymp. Sig. (2-tailed) & & .406 \\
\hline
\end{tabular}

Sumber: Data Primer, SPSS (2020)

Hasil dari tabel 4 diatas uji normalitas yang dimana menerapkan metode Kolmogrov Smirnov menunjukkan bahwa data penelitian telah terdistribusi normal hal ini dapat dibuktikan dengan Asymp.sig (2 tailed) sebesar $0.996>0.05$ dapat dikatakan bahwa penelitian terdistribusi normal.

Tabel 5 Uji Multikolinieritas

\begin{tabular}{|c|c|c|c|c|}
\hline \multirow[b]{2}{*}{ Model } & & & \multicolumn{2}{|c|}{ Collinearity Statistics } \\
\hline & & & Tolerance & VIF \\
\hline \multirow[t]{3}{*}{1} & $\begin{array}{l}\text { KUALITAS } \\
(\mathrm{X} 1)\end{array}$ & PRODUK & .968 & 1.034 \\
\hline & HARGA (X2) & & .994 & 1.006 \\
\hline & MEREK (X3) & & .964 & 1.037 \\
\hline
\end{tabular}

Sumber : Data Primer, SPSS (2020)

Hasil dari table 5 diatas menunjukkan bahwa nilai tolerance untuk variable Kualitas Produk, harga dan merek dalam tiap tiap model regresi lebih besar 0.10 dan nilai Value Inflating 
Factor (VIF) untuk variable kualitas produk, harga dan merek dalam tiap tiap regresi lebih kecil dari 10.00. Hasil pengujian ini mengindikasikan bahwa dalam model modell regresi yang digunakan dalam penelitian ini tidak terjadi gejala Multikolinieritas.

Tabel 6 Uji Heterokedastisitas

\begin{tabular}{|c|c|c|c|c|c|c|c|}
\hline \multirow[b]{2}{*}{ Model } & & & \multicolumn{2}{|c|}{ Unstandardized Coefficients } & \multicolumn{2}{|c|}{$\begin{array}{l}\text { Standardized } \\
\text { Coefficients }\end{array}$} & \multirow[b]{2}{*}{ Sig. } \\
\hline & & & B & Std. Error & Beta & $t$ & \\
\hline \multirow[t]{4}{*}{1} & (Constant) & & 4.194 & 1.395 & & 3.006 & .003 \\
\hline & $\begin{array}{l}\text { KUALITAS } \\
\text { (X1) }\end{array}$ & PRODUK & -.062 & .038 & -.164 & -1.623 & .108 \\
\hline & HARGA (X2) & & -.041 & .052 & -.078 & -.784 & .435 \\
\hline & MEREK (X3) & & -.050 & .047 & -.108 & -1.064 & .290 \\
\hline
\end{tabular}

Sumber: Data Primer, SPSS (2020)

Berdasarkan Tabel 6 diatas menunjukan jika seluruh variabel independen yaitu Kualitas Produk $\left(\mathrm{X}_{1}\right)$, Harga $\left(\mathrm{X}_{2}\right)$, dan Merek $\mathrm{X} 3$ ) tidak terjadi heterokedastisitas lantaran nilai signifikansinya $>0,05$. Hasil tersebut menunjukan bahwasama sekali tidak ditemukan kesamaan variance dari residual satu pengamatan ke pengamatan lain.

Tabel 7 Uji F

\begin{tabular}{rllllll}
\hline \multicolumn{2}{l}{ Model } & \multicolumn{2}{l}{ Sum } & \multicolumn{2}{l}{ of } & Mean \\
Square & F & Sig. \\
\hline $1 \quad$ Regression & 348.798 & 3 & 116.266 & 48.243 & $.000^{\text {a }}$ \\
& Residual & 231.362 & 96 & 2.410 & & \\
& Total & 580.160 & 99 & & & \\
\hline
\end{tabular}

Sumber: Data Primer, SPSS (2020)

Dilihat dari hasil perhitungan uji f pada table 7 diatas diperoleh uji f hitung sebesar 48.243 dan nilai signifikansi sebesar $0.000>0.05$, maka riset ini dikatakan terdapat pengaruh yang signifikan dari variable Kualitas produk, Harga dan Merek terhadap Keputusan pembelian.

\section{Tabel 8 Uji t}

\begin{tabular}{|c|c|c|c|c|c|c|c|}
\hline \multirow[b]{2}{*}{ Model } & & & \multicolumn{2}{|c|}{ Unstandardized Coefficients } & \multicolumn{2}{|c|}{$\begin{array}{l}\text { Standardized } \\
\text { Coefficients }\end{array}$} & \multirow[b]{2}{*}{ Sig. } \\
\hline & & & B & Std. Error & Beta & $\mathbf{T}$ & \\
\hline \multirow[t]{4}{*}{1} & (Constant) & & -4.688 & 2.355 & & -1.990 & .049 \\
\hline & $\begin{array}{l}\text { KUALITAS } \\
(\mathrm{X} 1)\end{array}$ & PRODUK & .596 & .065 & .602 & 9.184 & .000 \\
\hline & HARGA (X2) & & .196 & .088 & .144 & 2.228 & .028 \\
\hline & MEREK (X3) & & .449 & .079 & .375 & 5.719 & .000 \\
\hline
\end{tabular}

Sumber: Data primer, SPSS (2020) 
Berdasarkan tabel 8 maka dapat dikatakan bahwa semua variable yang terlibat berpengaruh terhadap Keputusan Pembelian. Penjelasan nya sebagai berikut:

1. $\mathrm{H}_{1}:$ Keputusan pembelian dipengaruhi oleh Kualitas produk Nature Leaf..

Dilihat dari hasil uji regresi berganda menunjukkan bahwa variable Kualitas Produk mempunyai koefisien regresi positif sebesar 0.596 dan mempunyai $t$ hitung $(9.184)>$ (1.985) dengan nilai signifikan sebesar $0.000<0.05$. Hal ini berarti $\mathrm{H}_{1}$ diterima yang berarti jika keputusan pembelian dipengaruhi Oleh Kualitas Produk

2. $\mathrm{H}_{2}$ : Keputusan pembelian dipengaruhi oleh Harga Nature Leaf.

Dilihat dari hasil uji regresi berganda menunjukkan bahwa variable Harga mempunyai koefisien regresi positif sebesar 0.196 dan mempunyai $t$ hitung $(2.228)>(1.985)$ dengan nilai signifikan sebesar $0.028<0.05$. Hal ini berarti $\mathrm{H}_{2}$ diterima yang berarti Keputusan pembelian dipengaruhi oleh Harga

3. $\mathrm{H}_{3}$ : Keputusan Pembelian dipengaruhi oleh Merek Nature Leaf.

Dilihat dari hasil uji regresi berganda menunjukkan bahwa variable Merek mempunyai koefisien regresi positif sebesar 0.449 dan mempunyai $t$ hitung (5.719) > (1.985) dengan nilai signifikan sebesar $0.000<0.05$. Hal ini berarti $\mathrm{H}_{3}$ diterima yang artinya Keputusan pembelian dipengaruhi oleh Merek.

Tabel 9 Koefisien Determinasi

\begin{tabular}{llllc}
\hline Model & R & R Square & $\begin{array}{l}\text { Adjusted } \\
\text { Square }\end{array}$ & $\begin{array}{c}\text { R Std. Error of } \\
\text { the Estimate }\end{array}$ \\
\hline 1 & $.775^{\mathrm{a}}$ & .601 & .589 & 1.552 \\
\hline
\end{tabular}

Sumber: Data primer, SPSS (2020)

Berdasarkan table 9 diatas, nilai Adjusted R Square (Koefisien Determinasi) sejumlah 0.589 yang artinya pengaruh variable Kualitas produk, Harga dan Merek terhadap keputusan pembelian sebesar 58,9\% dan 41,1\% dipengaruhi oleh variable lain.

Tabel 10 Uji Regresi Linier Berganda

\begin{tabular}{|c|c|c|c|c|c|c|}
\hline \multirow[b]{2}{*}{ Model } & & \multicolumn{2}{|c|}{ Unstandardized Coefficients } & \multicolumn{2}{|l|}{$\begin{array}{l}\text { Standardized } \\
\text { Coefficients }\end{array}$} & \multirow[b]{2}{*}{ Sig. } \\
\hline & & $\mathrm{B}$ & Std. Error & Beta & $\mathbf{T}$ & \\
\hline \multirow[t]{4}{*}{1} & (Constant) & -4.688 & 2.355 & & -1.990 & .049 \\
\hline & KUALITAS PRODUK (X1) & .596 & .065 & .602 & 9.184 & .000 \\
\hline & HARGA (X2) & .196 & .088 & .144 & 2.228 & .028 \\
\hline & MEREK (X3) & .449 & .079 & .375 & 5.719 & .000 \\
\hline
\end{tabular}

Sumber: Data Primer, SPSS (2020)

Dari tabel 10 diatas dapat diperoleh persamaan regresi agar dapat mengetahui pengaruh Kualitas Produk, Harga dan Merek terhadap keputusan pembelian sebagai berikut :

$$
Y=-4.688+0.596 X_{1}+0.196 X_{2}+0.449 X_{3}
$$

Keterangan:

$\mathrm{Y}=$ Keputusan Pembelian

$\mathrm{X} 1$ = Kualitas Produk

$\mathrm{X} 2$ = Harga

$\mathrm{X} 3=$ Merek 
Dapat dilihat dari hasil analisis regresi linier berganda diatas, dapat diperoleh persamaan sebagai berikut:

1. Nilai konstanta yang terbentuk adalah -4.688 atau negatif. Hal ini menunjukkan bahwa jika tidak memiliki hubungan antara variable kualitas produk, harga, dan Merek karena variable keputusan pembelian akan berkurang.

2. Pada persamaan regresi memperlihatkan jika variable kualitas produk mempunyai nilai 0.596 atau positif yang berarti bahwa kualitas produk mempunyai pengaruh positif terhadap keputusan pembelian, dan apabila semakin tinggi kualitas produk maka keputusan pembelian akan meningkat.

3. Pada persamaan regresi menunjukkan bahwa variable harga mempunyai nilai 0.196 atau positif yang berarti bahwa harga mempunyai pengaruh positif terhadap keputusan pembelian, dan apabila semakin tinggi harga maka keputusan pembelian akan meningkat.

4. Pada persamaan regresi menunjukkan bahwa variable Merek mempunyai nilai 0.449 atau positif yang berarti bahwa Merek mempunyai pengaruh positif terhadap keputusan pembelian, dan apabila semakin tinggi Merek maka keputusan pembelian akan meningkat.

\section{Keputusan Pembelian dipengaruhi oleh Kualitas Produk}

Dilihat dari riset diatas menrangkan jika keputusan pembelian dipengaruhi oleh kualitas produk nature leaf. Jika kualitas produk sesuai keinginan pasar maka pembelian akan product meningkat. Maka hipotesis yang pertama dapat diterima, dimana menjelaskan adanya keterkaitan antara keputusan pembelian dengan kualitas produk.

\section{Keputusan Pembelian dipengaruhi oleh Harga}

Dilihat dari riset diatas menrangkan jika keputusan pembelian dipengaruhi oleh harga nature leaf. Jika hargasesuai keinginan pasar maka pembelian akan product meningkat. Maka hipotesis yang kedua dapat diterima, dimana menjelaskan adanya keterkaitan antara keputusan pembelian dengan harga nature leaf sendiri.

\section{Keputusan pembelian dipengaruhi oleh Merek}

Dilihat dari riset diatas menrangkan jika keputusan pembelian dipengaruhi oleh merek nature leaf. Merek ialah gambaran dari product, jika company bisa meng-interprestasikan dengan jelas dengan begitu konsumen mudah mengigatnya. Maka hipotesis yang ketiga dapat diterima, dimana menjelaskan adanya keterkaitan antara keputusan pembelian dengan kualitas produk.

\section{PENUTUP}

Berdasarkan penelitian ini diketahui keputusan pembelian hand sanitizer Nature leaf pada remaja di Surakarta dipengaruhi oleh Kualitas Produk, Harga dan Merek. Hasilnya dapat dilihat jika variable kualitas produk Nature Leaf berpengaruh signifikan, untuk variable harga menunjukkan adanya pengaruh signifikan dan Untuk variable Merek menunjukkan adanya pengaruh signifikan yang artinya Keputusan pembelian Nature Leaf pada remaja di Surakarta dipengaruhi oleh Merek. Keterbatasan dalam penelitian ini adalah sulitnya mendapat jurnal yang cocok untuk menjadi acuan penelitian. Saran untuk penelitian ini sebaiknya Nature Leaf harus tetap mempertahankan kualitas produk dan harga mereka agar semakin banyak yang menggunakan produknya, dan dapat menjadi acuan untuk penelitian selanjutnya. 
DAFTAR PUSTAKA

Aaker, David, A .2008. Manajemen Ekuitas Merek, alih bahasa : Aris Ananda, Mitra Utama, Jakarta

Ananta, R. D. (2018). PENGARUH KUALITAS PRODUK DAN PERSEPSI HARGA TERHADAP KEPUTUSAN PEMBELIAN YANG DIMEDIASI OLEH CITRA MEREK (Studi Pada Pengguna Motor Yamaha R15 di Yogyakarta).

Basu Swastha, 2007, Manajemen Pemasaran Modern, Liberty Offset, Yogyakarta

Igir, F. G., Tampi, J. R., \& Taroreh, H. (2018). Pengaruh Kualitas Produk Dan Harga Terhadap Keputusan Pembelian Mobil Daihatsu Grand Max Pick Up (Studi pada PT. Astra International Tbk Daihatsu Cabang Malalayang). JURNAL ADMINISTRASI BISNIS (JAB), 6(002).

Kotler, Philip dan K.L Keller, 2008. Manajemen Pemasaran, Jilid 1, Penerbit Erlangga. Jakarta

Kotler dan Armstrong. (2008). Prinsip-prinsip Pemasaran 2. (edisi12). Jakarta: Erlangga

Kotler, Philip \& G. Amstrong. 2008. Prinsip Prinsip Pemasaran. Diterjemahkan oleh: Damos Sihombing, Jilid 1. Edisi 12. Jakarta: Penerbit Erlangga.

Kotler dan Keller. (2012). Marketing Managemen. (edisi 14). Global edition: Pearson Education.

Kotler, Philip dan Kevin Lane Keller. 2016. Marketing Management. Edisi 15. Pearson Education Inc.

Kotler,Philip and Keller Kevin Lane. (2012). Manajemen Pemasaran Edisi 11. Jilid 1. Jakarta: Erlangga

Putri, E. K. (2016). ANALISIS PENGARUH HARGA, KUALITAS PRODUK DAN IKLAN TERHADAP KEPUTUSAN PEMBELIAN KOSMETIK WARDAH (Studi pada Mahasiswi Universitas Muhammadiyah Surakarta) PUBLIKASI.

Sanjaya, S. (2015). Pengaruh promosi dan merek terhadap keputusan pembelian pada pt. Sinar sosro medan. Jurnal Ilmiah Manajemen dan Bisnis, 16(2).

Sarwono, J. (2012). Mengenal PLS-SEM. Yogyakarta: CV. Andi Offset.

Schiffman, Leon. G., \& Kanuk, Leslie Lazar. 2009. Perilaku Konsumen. Jakarta : PT. Indeks Group Gramedia

Sugiyono (2011) . Metode Penelitian Kuantitatif kualitatif dan R \& D. Alfabeta

Sugiyono. 2012.Metode Penelitian Bisnis. Bandung : Alfabeta

Sugiyono. (2017). Metode Penelitian Kuantitatif, Kualitatif, dan R\&D. Bandung: Alfabeta

Sujarweni, Wiratna. 2015. SPSS Untuk Penelitian. Yogyakarta : Pustaka Baru Press

Sutodjo, Siswanto. 2009. Manajemen Pemasaran, Edisi Kedua, Jakarta: Damar Mulia Pustaka

Syaleh, H. (2017). Pengaruh Kualitas Produk, Harga promosi dan Tempat Penditribusian terhadap Keputusan Pembelian Motor Yamaha pada Cv. Tjahaja Baru Bukit Tinggi. $1(1), 68-82$.

Tengor, Gloria, Lotje Kawet dan Sjendry Loindong. 2016. Pengaruh Merek, Desain Dan Kualitas Produk Terhadap Keputusan Pembelian Iphone Studi Kasus Pada Mahasiswa Stie Eben Haezar Manado. Jurnal Berkala Ilmiah Efisiensi Volume 16 No. 04 Tahun 2016.

Tjiptono, Fandy. 2010, Strategi Pemasaran, Edisi 2, Andi Offset, Yogyakarta

Uma Sekaran, 2011. Metode Penelitian Untuk Bisnis Edisi 14. Jakarta: Salemba Empat 